\title{
Square Mile
}

National Cancer Institute

\section{Source}

National Cancer Institute. Square Mile. NCI Thesaurus. Code C68872.

An imperial unit of area equal the area of a square of one mile in length on each side. It is equal to 2.589988 square kilometers, 640 acres, or 3097600 square yards, or 1/36 of a township. 